\title{
Financial Solving in Lodging Sector: Nakhon Pathom and Samut Songkram
}

\author{
Krisada Sungkhamanee
}

\begin{abstract}
The objectives of this paper are to study investment pattern suitable for lodging entrepreneur in Thailand, Nakhon Pathom and Samut Songkhram, to study the key factors level to invest, the status of factors that affect to lodging sector about investment pattern and design fit investment model for these 2 provinces. The data and information are collected from many sources, the libraries, many websites, and talking with Nakhon Pathom and Samut Songkhram Community leader and members, in - depth interview with 12 managers and 189 entrepreneurs. The results from this research show that the investment pattern is not related with location, types and shareholder register. Almost firms don't want to joint venture, they work with owner capital and some loans to gradually success with local culture in the name of "Nakhon Pathom and Samut Songkram Model". The result indicated that the status of Ownership specific, Location specific and Internalization specific were in very high level and much concern for them. The results of all factors were in accordance to the data obtained from the qualitative analysis technique which make the results of research clearer and more evidence. Suggestion from this research are government policies, infrastructure and area market influence on investment pattern decision, so The Royal Thai Government must help SME's service sectors rapidly to improve Thai economics specially after political conflict and natural disaster phenomena.
\end{abstract}

Index Terms-Financial solving, joint venture, lodging sector.

\section{INTRODUCTION}

Over the past 7 years, the impact of Globalization has increased dramatically. First of all Financial Crisis in the U.S. in 2005 has destroyed the real sector of Thailand: so balance of trade deficit over 30,000 Million Baht [1]. and Thailand have many problems in Politic also. The Royal Thai Government use service sector especially tourism industry to solve these difficult problems. So lodging sector faced to financial liquidity shortage. Second Financial Institutions didn't give new soft loan and they use high interest rate policy to limit credit to their customers. Then the entrepreneurs use the method of converted debt to new owners or joint venture to solve the difficult obstacles. Third in this area have 28 firms in Nakhon Pathom province and 161 firms in Samut Songkhram province [2]. which hadn't well systematic in financial arrangement because they almost are classical family business. All of these things urge the research team to studies the good tracks to solve Financial

Manuscript received July 20, 2012; revised August 25, 2012.

Krisada Sungkhamanee is with the Faculty of management Science, Suan Sunandha Rajabhat University, Bangkok, Thailand. (e-mail kris161988@yahoo.com).
Liquidity and searching about the important factors and levels of the influence that the entrepreneur use to decision in invest in lodging sector [3]. and finally the researcher want to make the investment pattern for these 2 provinces.

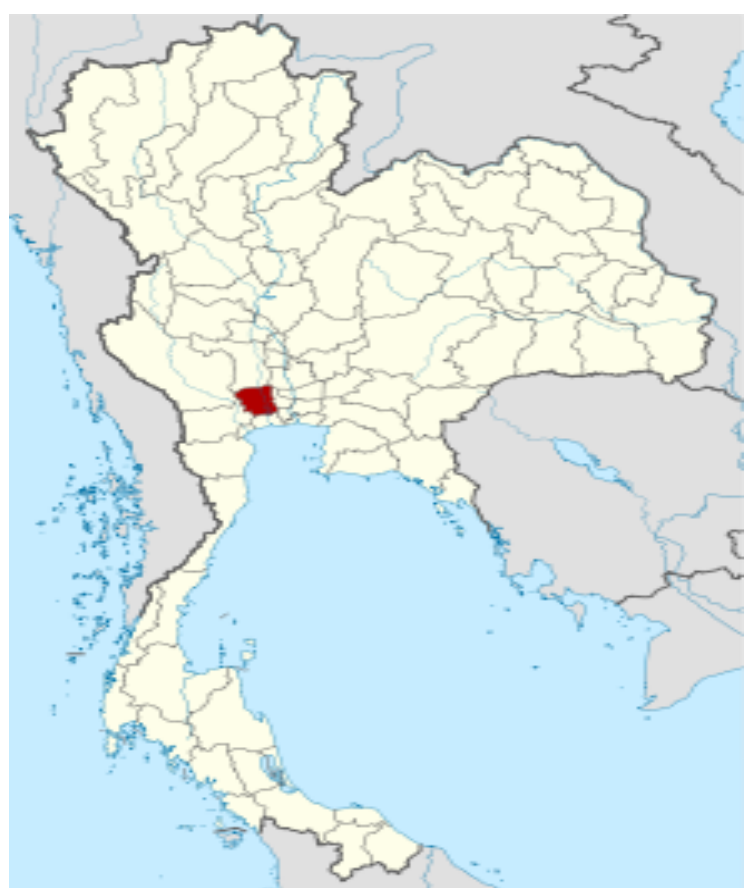

Fig. 1. Nakhon Pathom province in the map of Thailand

Nakhon Pathom is one of the central small provinces of Thailand and often referred as Thailand's oldest city. This province is 56 kilometers from Bangkok and has total area about $2,168.3 \mathrm{~km}^{2}, 866,064$ populations. This province is subdivided into 7 districts. The districts are further subdivided into 105 communes and 919 villages. There is one city and 14 townships. There are also 102 communes' administrative organizations. Major settlement of the province included emigration beginning in the reign of King Buddha Loetla Nabhalai (Rama II), which included Khmer villages, the Lanna populated and Lao Song villages, as well as a major influx of Southern Chinese in the late 1800s and early 1900s. Today Nakhon Pathom is attracts people from all over Thailand, most notably from Bangkok and the Northeastern, plus and Burmese migrant workers. The province includes industrial zones, major university towns, government offices relocated from Bangkok and agricultural and transport hubs. Mostly populations are in the field of agriculture, commerce and related to the field of cultural tourism. The capital city of Bangkok has grown until it actually encompasses the provincial boarder of Nakhon Pathom.

The interesting places which attract the tourist are consist 
of Wat Phra Pathom Chedi Ratchaworaviharn, Sanam Chan Palace, Buddhamonthon, King Monkut Klao Chaoyuhua Museum, Ya-Lei monument, Thai Human Imagery Museum, Sight-seeing by boats, Fruit orchards along Nakhon Chaisi river.

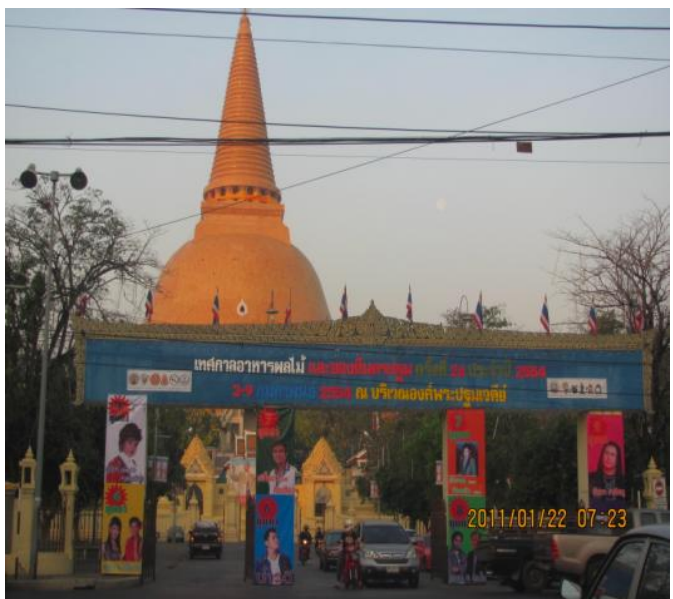

Fig. 2. Wat Phra Pathom Chedi Ratchaworaviharn

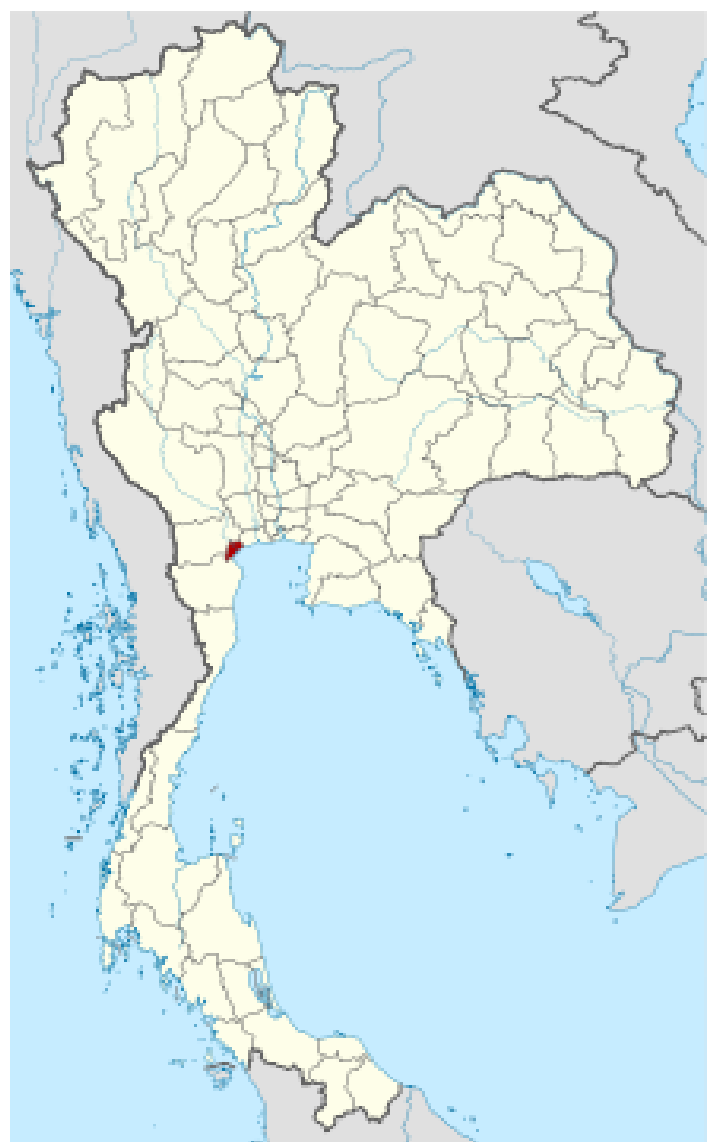

Fig. 3. Samut Songkram province in the map of Thailand

Samut Songkram is another one of the central and the smallest provinces of Thailand. The name "Mae Klong" is known as the second name of this province because of this city locating on the Mae Klong basin. This province is 72 kilometers from Bangkok and has total area about $416.7 \mathrm{~km}^{2}$, 194,086 populations. This province is subdivided into 3 districts. The districts are further subdivided into 38 communes and 284 villages. Mostly populations are in the field of agriculture, sea food, commerce and related to the field of cultural tourism especially home stay. The interesting places which attract the tourist are consist of a sandbank called Don Hoi Lot on the mouth of the Mae Klong River, Phet Samut Worawihan temple, Chang-Eng Siamese Twins Memorial and Boat Museum, Amphawan Chetiyaram temple, King Rama II Memorial Park and The Fair in Honour of King Rama II, The Lychee Fair, The Luangpho Ban Laem Fair, The Sunset at Don Hoi Lot Fair and Board Sliding Competition, The Khao Yai Pomelo Fair and The Mackerel Eating and Mae Klong Famous Products Festival.

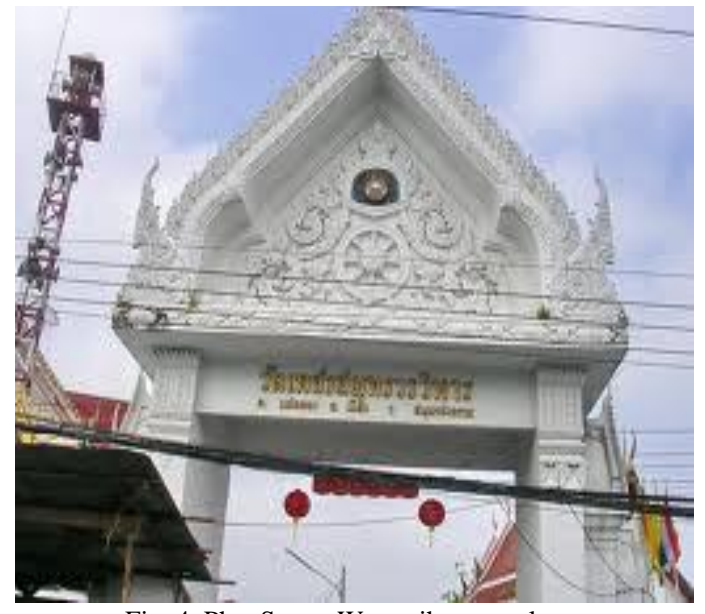

Fig. 4. Phet Samut Worawihan temple

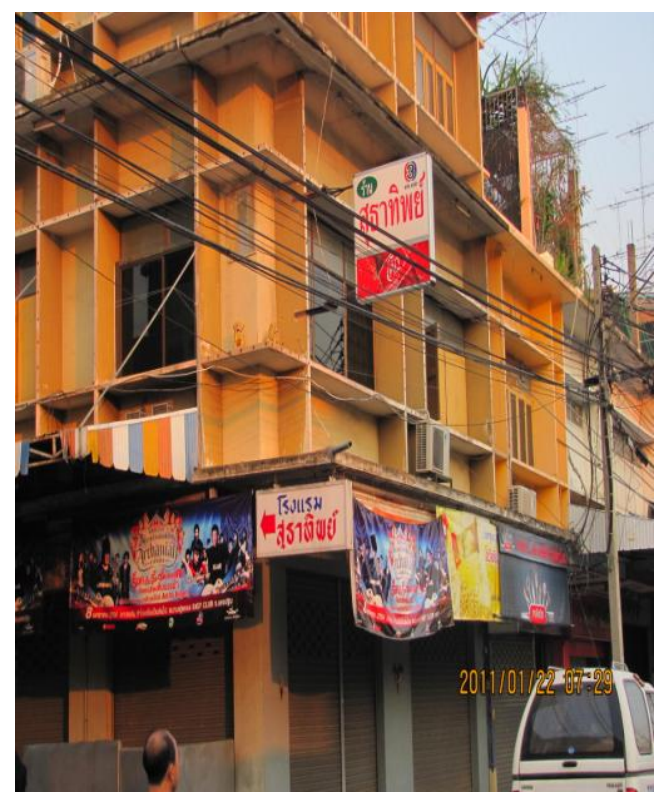

Fig. 5. Classical hotel in Nakhon Pathom province

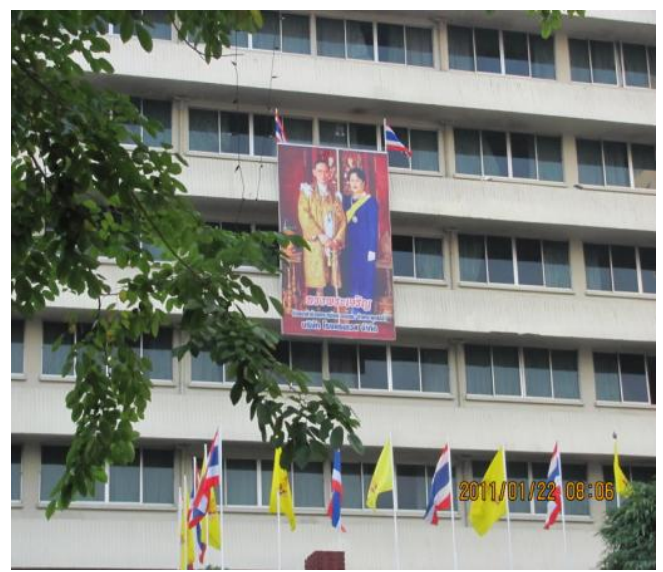

Fig. 6. Luxury hotel in Nakhon Pathom province 


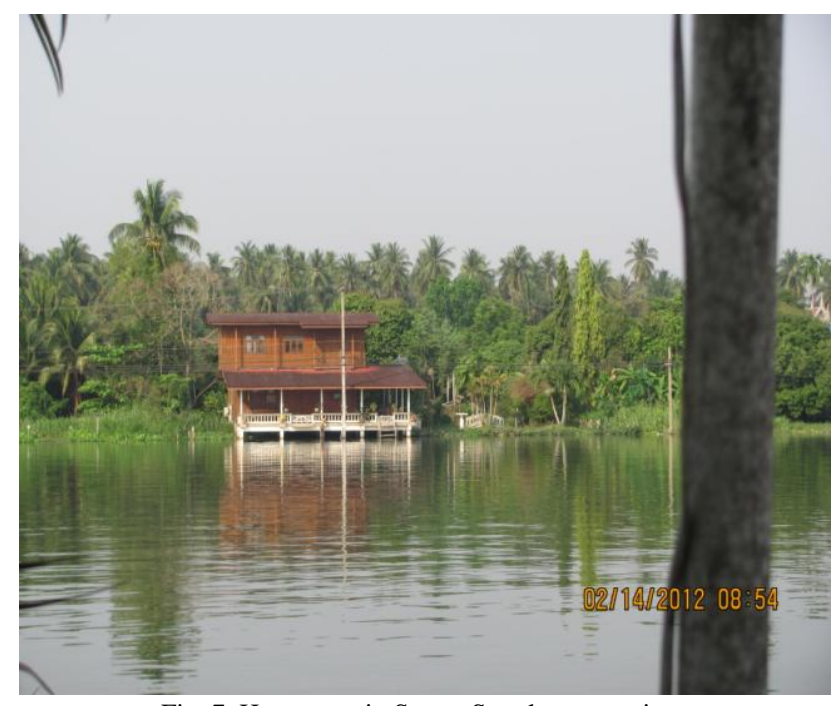

Fig. 7. Home stay in Samut Songkram province

\section{RESEARCH DESIGN AND DATA}

The goals of the empirical analysis came from 3 parts. Firstly the content which the researcher defined that whatever factors and levels of the influencing factors that lodging entrepreneur in Nakhon Pathom province and Samut Songkhram province use to decision in investment by review the literatures from many sources of information. The information are collected from the libraries and may websites so in the next step the researcher use the way of qualitative method by in depth interview with 12 managers systematically random process and confirm these results with the way of quantitative method with 189 questionnaires all area later. The binary logistic regression analysis and the chi-square test techniques have selected to confirm the interviewing before. By the way the 3 assumptions were below:

Assumption 1

$\mathrm{H}_{0}$ : Investment pattern do not relate to locations.

$\mathrm{H}_{1}$ : Investment pattern relate to locations.

The locations for this research were defied in the term of Nakhon Pathom province and Samut Songkhram province.

\section{Assumption 2}

$\mathrm{H}_{0}$ : Investment pattern do not relate to types of lodging.

$\mathrm{H}_{1}$ : Investment pattern relate to types of lodging.

The types of lodging for this research were defied in the term of hotel, resort and home stay.

Assumption 3

$\mathrm{H}_{0}$ : Investment pattern do not relate to types of register.

$\mathrm{H}_{1}$ : Investment pattern relate to types of register.

The types of register for this research were defined in the term of sole proprietorship, partnership and company.

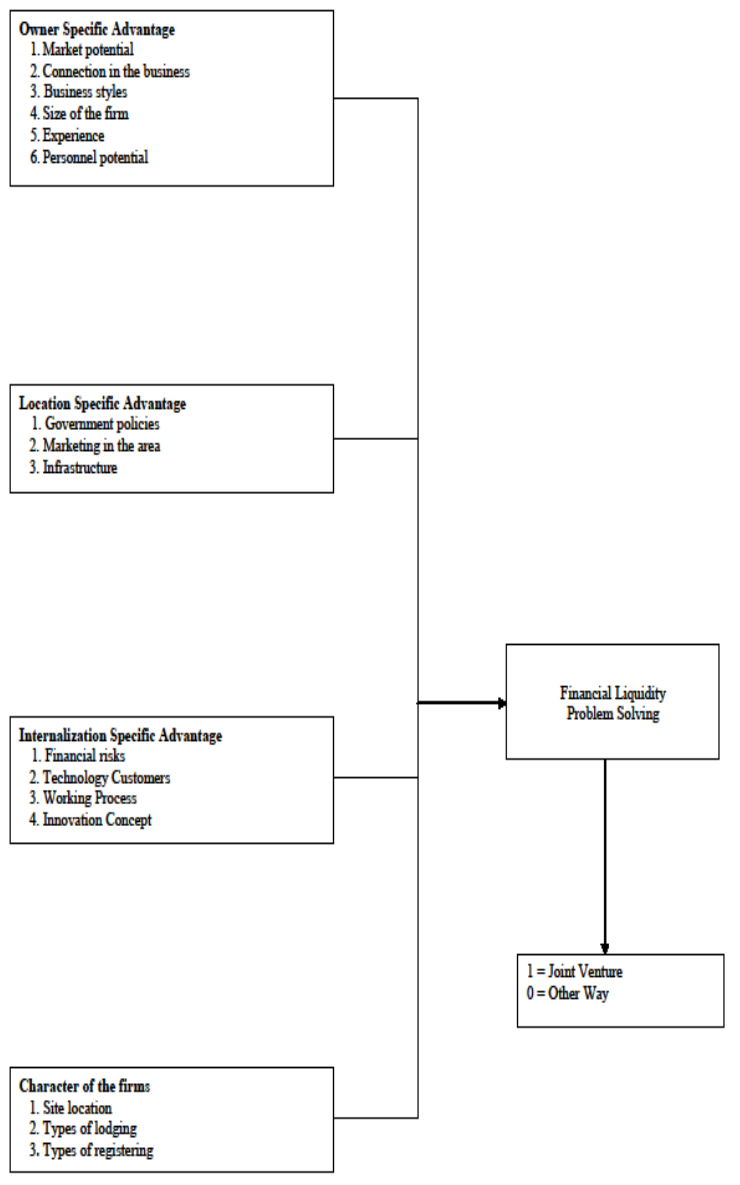

Fig. 8. Conceptual frame work of financial solving in Lodging

Secondly the time frame of this research started in October 2010 and continued to April 2011. Thirdly populations in this research were 189 owners from both provinces which consisted of all of types of lodging business located in Nakhon Pathom and Samut Songkhram.

TABLE II: THE BINARY LOGISTIC REGRESSION RESULTS

\begin{tabular}{|c|c|c|c|c|c|c|}
\hline & B & S.E. & Wald & & Sig. & $\operatorname{Exp}(B)$ \\
\hline \multicolumn{7}{|l|}{ Owner Advantage } \\
\hline Relation & -0.09 & 0.95 & 0.01 & 1 & .92 & 0.91 \\
\hline Pattern & 1.86 & 1.13 & 2.70 & 1 & .10 & 6.43 \\
\hline Experience & 0.90 & 1.53 & 0.35 & 1 & .56 & 2.46 \\
\hline Size & -0.27 & 1.31 & 0.04 & 1 & .84 & 0.77 \\
\hline $\begin{array}{l}\text { Potential of the } \\
\text { market }\end{array}$ & -0.07 & 0.60 & 0.01 & 1 & .91 & 0.94 \\
\hline Personnel potential & -0.45 & 1.12 & 0.16 & 1 & .69 & 0.64 \\
\hline $\begin{array}{l}\text { Location } \\
\text { Advantage }\end{array}$ & & & & & & \\
\hline $\begin{array}{l}\text { Government } \\
\text { policies }\end{array}$ & 0.13 & 0.72 & 0.03 & 1 & .86 & 1.13 \\
\hline Infrastructure & -2.34 & 1.11 & 4.42 & 1 & .04 & 0.10 \\
\hline $\begin{array}{l}\text { Market in the area } \\
\text { Internalization } \\
\text { Advantage }\end{array}$ & 3.01 & 1.24 & 5.90 & 1 & .02 & 20.28 \\
\hline Innovation & 2.13 & 1.34 & 2.52 & 1 & .11 & 8.43 \\
\hline Finance & 0.76 & 1.14 & 0.44 & 1 & .51 & 2.13 \\
\hline Technology & -0.42 & 0.54 & 0.59 & 1 & .45 & 0.66 \\
\hline Customer & -0.42 & 1.76 & 0.06 & 1 & .81 & 0.66 \\
\hline Process & -0.76 & 0.94 & 0.65 & 1 & .42 & 0.47 \\
\hline Constant & -18.51 & 10.71 & 2.99 & 1 & .08 & 0.00 \\
\hline
\end{tabular}




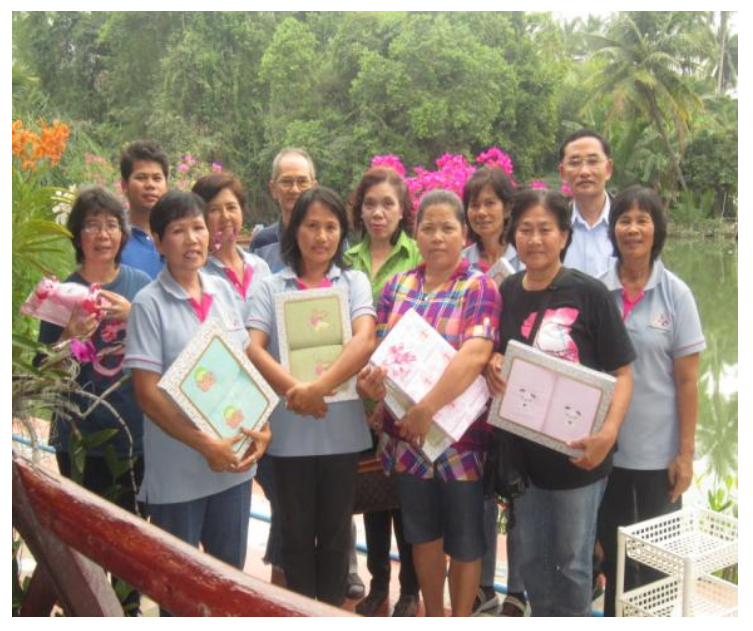

Fig. 9. Entrepreneurs in research areas

\section{RESULTS AND DISCUSSION}

After the data collection the qualitative research was further analyze through interviews of 12 randomly selected managers. Five Questions consisted of 1) How did your firm manage the problems of funding shortage situation? 2) What factors influenced your decision in solving financial liquidity problem and why? 3) How location in the district influence to decision in Solving Financial Problem and Why? 4) Did the types of lodging influence your decision in Financial Problem Solving and Why? And 5) Did the types of registering influence your decision in Solving Financial Problem and Why? The results found that all lodging business firms in Nakhon Pathom and Samut Songkhram aimed to invest individually, not joint venture. The results also revealed that people in this area had a significant identity: freedom. They did their business with a conservative and friendly style and they needed to promote the local culture, not profit orientation according with Culture and Personality Theories and Cultural Ecology Theory. Later research confirmed these results with quantitative research method later as shown.

TABLE I: PERCENTAGE OF FORECASTING THE RESULTS

\begin{tabular}{|c|c|c|c|c|c|}
\hline & & & \multicolumn{3}{|c|}{ Forecasting } \\
\hline & & & \multicolumn{2}{|c|}{$\begin{array}{c}\text { Investment } \\
\text { patterns }\end{array}$} & \multirow[t]{2}{*}{ Accuracy } \\
\hline & & & $\begin{array}{l}\text { Wholly } \\
\text { owned }\end{array}$ & $\begin{array}{c}\text { Joint } \\
\text { Venture }\end{array}$ & \\
\hline \multirow[t]{3}{*}{$\begin{array}{l}\text { Step } \\
0\end{array}$} & $\begin{array}{l}\text { Investment } \\
\text { patterns }\end{array}$ & $\begin{array}{l}\text { Wholly } \\
\text { Owned } \\
\text { Joint }\end{array}$ & 177 & 0 & 100.00 \\
\hline & Overall & Venture & 11 & 1 & 8.30 \\
\hline & Percentage & & & & 94.20 \\
\hline
\end{tabular}

The results from Table I show that this model could forecast 94.20 overall percent.

The results from Table II show that there were 2 independent variables in this model: infrastructure and market in the area. Thus Joint Venture probability model was

$$
\hat{P}(\mathrm{Y}=1)=\frac{1}{1+e^{-w}}
$$

$w=-18.51-2.34$ Infrastructure +3.01 Market

TABLE III: RELATION BETWEEN INVESTMENT PATTERNS AND LOCATION

\begin{tabular}{llccc}
\hline \hline & $\begin{array}{c}\text { Nakhon } \\
\text { Pathom }\end{array}$ & $\begin{array}{c}\text { Samut } \\
\text { Songkhram }\end{array}$ & Total \\
\hline $\begin{array}{l}\text { Investment } \\
\text { patterns }\end{array}$ & $\begin{array}{l}\text { Wholly } \\
\text { Owned } \\
\text { Joint } \\
\text { Venture }\end{array}$ & 23 & 154 & 177 \\
\hline & Total & 28 & 161 & 12 \\
\hline \hline
\end{tabular}

$$
\begin{gathered}
\chi^{2}=1.941 \text { Asymp. } \\
\text { Sig. }(2 \text {-sided })=0.379 \\
\text { Cramer's V }=0.110 \text { Approx. Sig. }=0.379
\end{gathered}
$$

The results from Table III show that investment pattern did

\begin{tabular}{|c|c|c|c|c|c|}
\hline \multicolumn{6}{|c|}{ LODGING } \\
\hline & & Hotel & Resort & $\begin{array}{c}\text { Home } \\
\text { stay }\end{array}$ & Total \\
\hline \multirow[t]{3}{*}{$\begin{array}{l}\text { Investment } \\
\text { patterns }\end{array}$} & $\begin{array}{l}\text { Wholly } \\
\text { Owned }\end{array}$ & 24 & 47 & 106 & 177 \\
\hline & $\begin{array}{l}\text { Joint } \\
\text { Venture }\end{array}$ & 4 & 1 & 7 & 12 \\
\hline & Total & 33 & 48 & 113 & 189 \\
\hline
\end{tabular}
not relate with location.

TABLE IV: RELATION BETWEEN INVESTMENT PATTERNS AND TYPES OF

$\chi^{2}=4.440$ Asymp. Sig. (2-sided) $=0.109$

Cramer's V $=0.153$ Approx. Sig. $=0.109$

The results from Table IV show that investment pattern did not relate with types of lodging.

\begin{tabular}{|c|c|c|c|c|c|}
\hline & & \multicolumn{4}{|c|}{ Types of registering } \\
\hline & & Sole & Partner & $\begin{array}{l}\text { Co. } \\
\text { ltd. }\end{array}$ & Total \\
\hline \multirow{3}{*}{$\begin{array}{l}\text { Investment } \\
\text { patterns }\end{array}$} & Wholly Own & 133 & 22 & 22 & 177 \\
\hline & Joint Venture & 7 & 1 & 4 & 12 \\
\hline & Total & 140 & 23 & 26 & 189 \\
\hline$\chi^{2}$ & 153 Asym & . $(2$ & ded) $=$ & .125 & \\
\hline
\end{tabular}

TABLE V: RELATION BETWEEN INVESTMENT PATTERNS AND TYPES OF REGISTER

The results from Table $\mathrm{V}$ show that investment pattern did not relate with types of register.

\section{CONCLUSION}

The researcher found 4 factors that influenced the lodging business in these two provinces: 1) Owner Specific Advantage which consisted of relation in the business, pattern of management team, experience of the firm, size of the firm, potential of the market, potential of personnel, 2) Location Specific Advantage which consisted of government policies, infrastructure, market in the area 3) Internalization Specific Advantage which consisted of innovation management concepts, financial risk management concepts, technological appliance, customer focus and work processing, and 4) Characteristics of the firms which consisted of site location, types of lodging, types of 
registering according with the research of Commitment and Opportunity Development in the Internationalization Process [4]. and the research of A Sociology of the Demonic? [5].

The results from qualitative research were confirmed by quantitative research that there were 2 independent variables in this model: infrastructure and market. In these two provinces investment patterns did not relate with location, did not relate with types of lodging and did not relate with types of registering. Lodging firms in Nakhon Pathom and Samut Songkhram needed to invest individually, not a joint venture. People in this area had significant identity: freedom. They did business with a conservative and friendly style. They needed to promote local culture, not profit orientation according with Culture and Personality Theories and Cultural Ecology Theory. These things shown the research team that the economic expansion did not growth rapidly but the economic would be growth with sustainability.

\section{RECOMMENDATIONS}

For the Royal Thai Government, the results might be considered when preparing financial liquidity for lodging entrepreneurs by the Bank of Special Purpose mechanism such as The Government Savings bank (GSB) and Small and Medium Enterprise Bank of Thailand (SME's bank). The GSB or SME's bank can help lodging firms by using low interest rate policy, giving grace period and expanding term of loans. In the same way government by Ministry of Finance should use taxation policy to help them, give academic knowledge under cooperation with Universities, and arrange events or festival in the tourism area to provide tourist incentive and impact to Hotel and Lodging business. The findings of this study should be of great value to organizations as they apply research results to investment promotion, strategic planning, policy adjustment and problem solution management. In this way Thailand can have economic expansion through the service sector, especially tourism.

\section{LIMITATION AND FUTURE RESEARCH}

Nowadays, tourism is an important service industry for growth in Thailand economics. Therefore, it is important to pay heed to the large segment especially lodging sector. This paper use the non random nature of the sample utilized by this qualitative research, in depth interview, is the primary limitation. This is due to the fact that these groups of entrepreneurs were urging to participate in this work. Consequently, the entrepreneurs who were unable to correspond in the questionnaire had assigned some person in his or her family to answer for the set of questions. Therefore may not be rightly generalized to the population of entrepreneur lodging. Further researches should explore the link between these areas and other areas in the northern of Thailand. However, keep in mind, there is one truth about the new areas to study must have characteristic in the tone of culture tourism and the entrepreneurs have shortage in financial situation.

\section{ACKNOWLEDGMENT}

This paper would not have been possible without the contribution, the supporting, the kindness helpful and the encouragement of Dr. Somdech Rungsrisawat, Assistant Professor Dr. Bundit Pungnirandr and Dr. Wittaya Mekkham from Suan Sunandha Rajabhat University.

\section{REFERENCES}

[1] Thai Chamber of Commerce, Thailand GDP Data and Country Report 2006. Bangkok, Thailand: Chuanpim, pp. 17-18.

[2] Tourism Authority of Thailand, Tourism Statistics 2011, Bangkok, Thailand: Amarin, pp. 13-14.

[3] J. Yang and H. Lee, "Identifying key factors for successful joint venture in China," Industrial Management Data System, vol. 102, no.. 2, pp. 98-109, 2002.

[4] J. Johanson, and J. Vahlnerant, "Commitment and Opportunity Development in the Internationalization Process: A Note on the Uppsala Internationalization Process Model," Journal of International Business Studies, vol. 46, no. 2, pp. 165-178, 2006.

[5] A. Weber, "A Sociology of the Demonic?" Journal of Classical Sociology, vol. 8, no. 1, pp. 89-108, 2008.

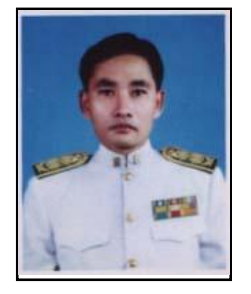

Krisada Sungkhamanee was born in Narathiwat province, which located in the south of Thailand on 20 September 1965 and received his B.B.A. degree in Accounting from Thammasat University in 1987, M.B.A. degree in Finance and Marketing from Chulalongkorn University in 1991 and Ph.D. degree in Innovative Management from Suan Sunandha Rajabhat University in 2010.

He used to work in many commercial banks and financial institutions for 10 years in the position of Vice President. Now he is an Assistant Professor at Suan Sunandha Rajabhat University, Bangkok, Thailand. His text books were Money and Banking, $3^{\text {rd }}$ ed. Bangkok, Thailand: Chulalongkorn University Press, 2011 and Credit Management $3^{\text {rd }}$ ed. Bangkok, Thailand: Chulalongkorn University Press, 2012 and his article was "Financial Liquidity Problem Solving in Hotel and Lodging: Nakhon Pathom \& Samut Songkram" in Proc. $3^{\text {rd }}$ International Conference on Education and management Technology, Singapore, 2012, pp. 21-24. His main research interests in the field of investment in tourism management and service sector.

Asst. Prof. Dr. Sungkhamanee is a member of the association of researchers, Thailand and he received funding from Suan Sunandha Rajabhat University to study and training in the topic of International Business at Indiana State University in 2008 and the course of research for developing country at The University of Queensland, Australia in 2012. 